\title{
PERROS Y LITERATURA: CONDICIÓN HUMANA Y CONDICIÓN ANIMAL
}

\author{
DOGS AND LITERATURE: THE HUMAN CONDITION \\ AND THE ANIMAL CONDITION
}

\section{BERNARDO SUBERCASEAUX ${ }^{* *}$}

\section{RESUMEN}

El artículo se propone relevar las representaciones e imaginarios perrunos, distinguiendo distintas modalidades en las literaturas hispánicas, europea y norteamericana. Plantea que en el capitalismo tardío y la masificación de las mascotas, se ha producido una osmosis entre la sociedad humana y la perruna, interacción que tiene su correlato en la literatura. Una osmosis que paradojalmente revela la humanidad de los animales y la insociabilidad y soledad espiritual del ser humano. Reafirmando el carácter específico del lenguaje literario como desocultamiento y revelación, el artículo plantea distintas variables -filosófica, científica e histórico-social- para abordar el corpus, e indagar los imaginarios perrunos en la literatura, sobre todo respecto a la condición humana vis a vis la condición animal, y también viceversa.

Palabras clave: Perros, imaginarios, condición humana, condición animal, especies, antropocentrismo, humanismo, posthumanismo.

\section{ABSTRACT}

This article explores canine representations and imaginaries in modern literature and culture, distinguishing different modes in Hispanic, American and European narratives. It is suggested that with the proliferation of mascots in late capitalism, osmosis has been produced between human and canine society, creating an interaction that has a correlation in literature. It is an osmosis that paradoxically reveals the humanity of animals and the unsociability and spiritual isolation of human beings. Reaffirming the

\footnotetext{
* El presente artículo se realiza en el marco del Proyecto Fondecyt 1100148 "Representaciones e imaginarios perrunos".

** Dr. en Literaturas y Lenguas Romances, Harvard. Profesor Titular Depto. Literatura Universidad de Chile. Santiago, Chile. E-mail: besuberc@uchile.cl
} 
specific character of literary language such as unconcealment and revelation, this article proposes distinct variables - philosophical, scientific and socio-historic- in order to address the corpus and question canine imaginaries in literature, above all in respect to the human condition vis a vis the animal condition and vice versa.

Key words: Dogs, imaginaries, human condition, animal condition, species, anthropocentrism, humanism, posthumanism.

Recibido: 16.06.13. Aceptado: 21.08.13.

\section{EL CORPUS}

$\mathrm{E}$

N LA Mitología grecolatina el perro Cerberos, conocido como Can Cerberos, fue representado como un monstruo de tres cabezas al cuidado de las puertas del inframundo. Más tarde figura en el Canto VI del Infierno, en La divina comedia, de Dante. Esta percepción monstruosa de lo perruno, visible en las gárgolas medievales y vinculada a la muerte, tuvo su temprana contraparte en Argos, el siempre leal perro de Ulises, el único que en la obra de Homero mueve la cola y lo reconoce cuando des-

MIGUEL DE CERVANTES SAAVEDRA

EL COLOQUIO

DE LOS PERROS CON SEIS AGUAFURRTES GRANYER

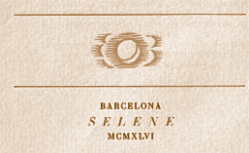
pués de veinte años el héroe regresa a Ítaca. Esopo, alrededor del 600 a.C., en sus Fábulas, recurre a perros humanizados y moralizantes como una forma oblicua de enseñar. Hay crónicas de la Conquista que mencionan perros participantes en la "empresa", varios de los cuales, luego de los botines, recibían una paga, como si fuesen soldados (según el cronista Gonzalo Fernández de Oviedo, uno de ellos fue el perro Becerrillo que acompañó al conquistador Alonso de Salazar $)^{1}$. Pero será sobre todo a partir del renacimiento europeo y del inicio de la modernidad, que los perros adquieren una presencia literaria sostenida, dando lugar, como ocurre con la novela de Cervantes El casamiento engañoso y El coloquio de los perros (1613), a una tradición de narradores o personajes perrunos en las letras hispánicas. En la literatura chilena, en Las aventuras de cuatro remos (1883) de Daniel Barros Grez y en Memorias de un perro, escritas por su propia pata (1893) de Juan Rafael Allende, encontramos perros narradores (en clave picaresca) o perros parlantes que piensan y viven humanamente pero que también se comportan y actúan como perros. Tradición cervantina que se prolonga hasta el perro narrador cibernético, de Indiscreciones de un perro gringo (2007), del puertorriqueño Luis Rafael Sánchez. Otra dimensión cervantina, la Quijotesca, es apropiada por José Fernández de Lizardi en La quijotita

\footnotetext{
${ }^{1}$ Para un registro histórico de los imaginarios perrunos, véase Andrade Kabayashi (2011).
} 
y su prima (1815), novela en que se recurre a imaginarios perrunos, pero en clave ilustrada. Incluso E.T Hoffman, autor germano, recreó Las últimas noticias de la suerte del perro Berganza (1814), en que el can cervantino dialoga con el autor pero sin asumir el modelo de la picaresca.

En los últimos siglos la interacción hombre-perro se incrementa considerablemente con la masificación de los perros de hogar. Situación que tiene como correlato una abundante producción ficticia que aborda distintos aspectos de esa relación. En la literatura norteamericana de comienzos del siglo XX, en un notable par de novelas, Jack London lleva a cabo un tratamiento realista y en clave darwiniana del perro, en que relata un viaje de ida y vuelta desde un perro domesticado a su ancestro lobo en El llamado de la selva (1903); y, desde un lobo a un perro casero de la costa de California, en Colmillo blanco (1906). Pero los perros han sido también soporte ficticio de indagaciones de corte filosófico y existencial, por ejemplo, en Investigaciones de un perro (1922), el relato de Franz Kafka en que el narrador fluye entre su animalidad y su humanidad. Registro en que también puede inscribirse, con el agregado de una mirada social, cristológica y con rasgos picarescos, la novela Patas de perro (1965) de Carlos Droguett. Otra línea es el recurso del tema perruno en la sátira política y humana, registro magistralmente logrado en Corazón de perro, la novela del ruso Mijaíl Bulgakov (1925), relato en que el "hombre nuevo" que propone el socialismo es caricaturizado en la figura de un perro manipulado quirúrgicamente. La novela de Bulgakov, que satiriza el sistema soviético, se diferencia de Rebelión en la granja (1945) de George Orwell, puesto que esta última se rige integralmente por el principio de la alegoría: los animales -perros incluidos- dejan de serlo en la medida que apuntan a un segundo orden correlativo de carácter histórico-social. También se inscribe en un registro satírico burlesco Indiscreciones de un perro gringo, el testimonio de un perro de la Casa Blanca que presenció los encuentros entre el Presidente Clinton y Mónica Lewinsky (recreados como ya señalamos con intertextualidad cervantina). Hay además un grupo de obras autobiográficas o memorialistas que abordan el territorio de lo íntimo con la mirada de un perro, o a través de una relación entre perro y amo: Señor y perro (1918) de Thomas Mann; Flush (1933) de Virginia Woolf; Todos los perros de mi vida (1936) de Elizabeth von Arnim; Mi perra Tulip (1956) de John Ackerley y Cecil (1972), del argentino Manuel Mujica Láinez². Cabe por último señalar que hay un

\footnotetext{
${ }^{2}$ Debo el conocimiento de estas tres novelas y la atención al tema de lo íntimo en la literatura perruna a Julieta Yelin, investigadora argentina, autora de "La voz de su amo. De la biografía (y la autobiografía) animal" (2010: 91-93).
}

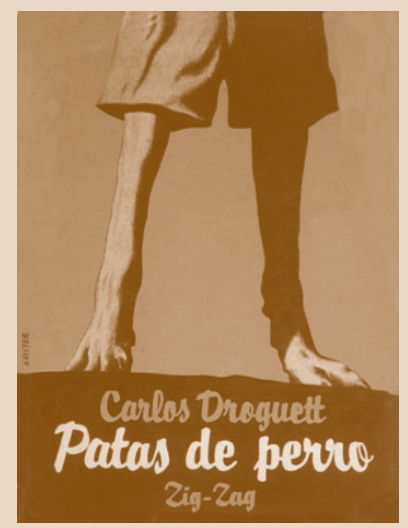



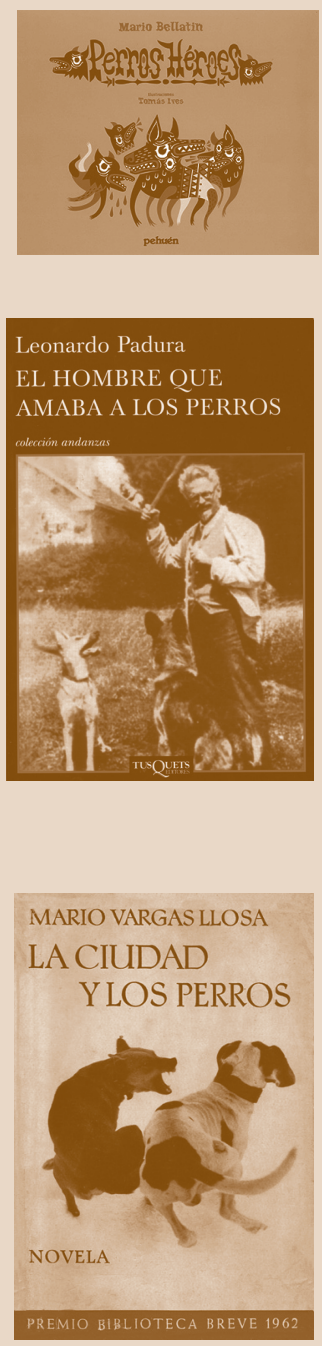

número importante de narradores latinoamericanos actuales que recurren a imaginarios, a motivos o a temas perrunos en clave posmoderna, entre otros, el colombiano Fernando Vallejo en Los días azules (1985), Entre fantasmas (1993) y El don de la vida (2010); el mexicano Mario Bellatin en Perros héroes. Tratado sobre el futuro de América Latina visto a través de un hombre inmóvil y sus treinta pastor belga Malinois (2003) y Disecado (2011). También, aunque en un registro distinto, el cubano Leonardo Padura en El hombre que amaba a los perros (2009).

A este corpus de autores que se pasean por los intersticios de la condición humana en interacción con el imaginario perro (y que también, de paso, indagan, la condición animal), habría que agregar un número importante de novelas, de obras de teatro y poemarios que recurren en sus títulos al imaginario perruno o a la voz "perro", aspecto no menor si consideramos que los títulos son casi siempre una síntesis de la voluntad compositiva del autor, y, por lo tanto, un referente que de manera directa o indirecta alude a un sentido totalizador de la obra. Estamos pensando, entre otros, en los relatos "Mi perro negro"(1908) de Fernando Santiván, "El perro rabioso" (1917) de Horacio Quiroga y "Ojos de perro azul" (1950) de Gabriel García Márquez; en la obra de teatro Los perros (1918) de Armando Mook; en las novelas La ciudad y los perros (1963) y Los cachorros (1967) de Mario Vargas Llosa; en Perro come perro (1996) del escritor norteamericano Edward Bunker; en El poder del perro (2005) del también norteamericano Don Winslow; en Hasta que me orinen los perros (2007) del peruano Gonzalo Ampuero; en Perros de nadie (2008) del argentino Esteban Valentino, y en Carne de perra (2009) de la chilena Fátima Sime. Y la lista podría seguir y seguir, agregando novelas, obras de teatro e incluso poemarios en que el hablante lírico asume la voz de un perro.

Pero los imaginarios perrunos no sólo están presentes en la cultura ilustrada, también se los encuentra en la cultura popular y en la cultura de masas. En el saber popular expresado en refranes, proverbios o dichos, un saber que recurre de preferencia a los perros más que a cualquier otro animal: entre otros "Perro que ladra no muerde", "Perro con corbata nadie lo mata", "Matando la perra se corta la leva", "Más tonto que perro nuevo", "Donde hay un hueso hay un perro", "Al de atrás lo muerde el perro", "Hasta el perro fino tiene pulgas", "El perro del hortelano no come ni deja comer", "A otro perro con ese hueso", "Como perros y gatos", "Tranquilo el perro", "Hacer perro muerto", "Vida de perros", "Perro viejo" y así, suma y sigue.

Por último están los perros que deambulan por la cultura de masas, provenientes sobre todo de la industria cultural norteamericana, perros como 
Pluto, Scooby Doo, Rex, Rin Tin Tin, Lassie, Tribilín, La Dama y el Vagabundo, Goofy, Snoopy o los 101 Dálmatas, también algunos ejemplares locales, como Spike: el quiltro símbolo publicitario de la empresa chilena Lipigas.

No cabe duda que esta presencia de las representaciones perrunas en el capital simbólico que circula en la sociedad se debe a que el ser humano con el animal que mayor, mas continua y afectuosa interacción ha tenido -a lo largo de su historia- es con el perro. Ya en el siglo IV a.C. se le atribuye a Diógenes de Sinope (o Diógenes el cínico) la frase "cuanto más conozco a los hombres más quiero a mi perro". Según Miguel de Castro, soldado y escritor español del siglo de oro, "la raza canina ha contribuido, sin proponérselo, a embellecer la historia, la leyenda y la poesía, cosa que no han logrado historiadores y poetas a pesar de habérselo propuesto" (De Castro, 1900, cit. por Monner Sans, 1923). Desde la antigüedad, con la domesticación, pero sobre todo con la masificación de la industria de las mascotas en el capitalismo tardío, se ha ido produciendo una osmosis entre la sociedad humana y la sociedad perruna. Cada vez más los perros son concebidos como seres humanos y los seres humanos como entes que han reprimido su cuerpo y su animalidad. Situación que incide también en el contexto de recepción y en el horizonte de expectativas de lectura de estas ficciones.

¿Cómo abordar, entonces, este extenso y diverso corpus de representaciones literarias y culturales desde una perspectiva múltiple y crítica? ¿Cómo hacerlo desde una mirada que permita productivizar el tema, que estimule la reflexión tanto sobre la literatura como sobre la sociedad, que posibilite abordar el pensamiento contemporáneo sobre la condición humana y la "máquina antropocéntrica" y y también sobre la condición animal y las relaciones con un "otro" significativo? Proponemos, con este fin, abordar esta tarea teniendo en mente cuatro variables que aportan distintos ángulos de reflexión y análisis: son la variable histórico-social, la estéticoliteraria, la científica y la variable filosófica.

\section{VARIABLE HISTÓRICO-SOCIAL}

El chacal africano (canis aureus) y el lobo asiático (canis lupus) conforman las dos ramas de un tronco común del cual provienen todas las subespecies de perros que conocemos hoy día (Lorenz, 1975). También aquellas que

\footnotetext{
${ }^{3}$ Metáfora que apunta al uso permanente del interés y punto de vista de la especie humana en la visión y el uso de la naturaleza y de todo lo existente.
} 
se derivan de estas últimas y que han sido creadas artificialmente en los últimos dos siglos, las que conforman la mayoría de las más de 400 razas actuales. Con respecto al pasado remoto, se ha logrado datar fósiles de perros domesticados ya en el 8400 a.C., lo que ha llevado a calcular que la domesticación de perros en funciones de caza o de recolección se produjo entre diez y catorce mil años atrás (Lorscheider-House, 2003; Fox, 1978). En el mundo antiguo, en Grecia y Roma, los perros domesticados cumplían funciones de guardianes, de pastoreo e incluso de apoyo en las guerras. En España, en el siglo XVII, un tratado de Ballestería y Montería habla de distintas castas y oficios perrunos: menciona al lebrel o galgo al que destaca por su rapidez, al alano (mezcla de dogo y lebrel), al dogo como un perro grande y servicial, al mastín como guardián del rebaño, al sabueso (oriundo de Saboya), al perro de aguas (lanudo que se arroja al agua para rescatar la caza), al zorrero, al perro de encargo (que busca la caza y la levanta) y al perro de ajeo (perdiguero). En definitiva perros con funciones específicas en torno a la cacería (Martínez de Espinar, 1644, cit. en Monner Sans, 1923). Sabemos también -por la pintura de los siglos XV al XVIII- de perros más pequeños -casi siempre malteses- que aparecen en primer plano con sus amos, que cumplen sólo funciones de compañía en los "jardines del amor" (alegoría del paraíso) o en ambientes aristocráticos y palaciegos europeos. Se trata, entre otros, de pintores como Renaud de Montaubon, Boticelli, Ticiano, Velázquez, Murillo y Goya.

El tránsito desde lobos y chacales a perros de compañía se da en el transcurso de miles de años, período en que la domesticación implicó la pérdida parcial de instintos (entendemos los instintos como pautas heredadas de comportamiento) y el aprendizaje de hábitos o conductas ajustados a sus nuevos espacios de vida y alimentación. Pero va a ser sobre todo en la modernidad capitalista en que el número de perros de compañía tiene una explosión sin precedentes. Situación que se da en un contexto de migración del campo a la ciudad y de un aumento considerable de la vida urbana, en que el perro con fines utilitarios (pastoreo, caza) va dando paso a mascotas sin fines prácticos (Yelin, 2011). Datos del año 2006 indican que en los Estados Unidos había en esa fecha 74 millones de perros y en Europa otros 70 millones; Donna J. Haraway habla de un global companion-animal industry y de un mercado de alimentos para mascotas en USA de 15 billones de dólares anuales, sumados a un gasto por año de 10 billones de dólares en salud perruna (Haraway, 2008). Un estudio de la Universidad Iberoamericana de Ciencias y Tecnología indica que en Santiago, en el año 2010, había 1.346.871 perros domésticos, 500 mil más de los que había doce años atrás 
(Aravena, 2010). La gran diferencia entre países considerados desarrollados y algunos países de América Latina, Chile entre ellos, es la enorme cantidad de perros vagos, de perros callejeros sin casa que hay en estos últimos. Lo que une, empero, al norte y al sur, son los millones y millones de perros en viviendas urbanas y rurales, perros que funcionan casi como miembros del grupo familiar, que tienen nombre, derecho a cama o caseta, comida y baño.

En la interacción hombre/perro vivimos en todos los continentes una presencia creciente de la máquina antropocéntrica. Los perros ejercen muchos de los oficios que practican los seres humanos. Hay perros que funcionan como guardias en espacios públicos y privados, perros-policías que se pasean por los aeropuertos olfateando drogas o artefactos explosivos. Perros enfermeros que facilitan la vida a personas no videntes. Perros entrenados para detectar las bajas de glicemia en personas diabéticas. Perros terapeutas que ayudan a curar las depresiones y que avisan de ataques epilépticos, que guían a niños y a adultos con impedimentos físicos. Hay zoológicos (el Zafari Park y el Taiyuan Zoo, en China) en que las perras funcionan como madres sustitutas de otras especies abandonadas por sus madres (osos, lobos, leones y tigres). Hay perros acróbatas y gimnastas, perros que hacen deporte, que corren carreras o pelean entre sí para deleite de los aficionados; también perros que actúan en películas, en programas de Televisión o que se transforman en estrellas de la publicidad. Hay perros Pitbull y Rottweiler que figuran a menudo -como delincuentes- en la crónica roja de los periódicos. Hay, incluso, perros de ficción, que escriben novelas.

En la sociedad perruna hay también fenómenos de inclusión y exclusión, segregación, estamentos y marginalidad, diferencias entre perros que reproducen las diferencias que se dan en la sociedad. Hay perritas fifís, enchuladas, perros de raza que poseen linaje, árbol genealógico y pedigrí, que meriendan en recipientes especiales y participan (siguiendo el patrón del american way of life) en certámenes de belleza o de adiestramiento. Otros que son simplemente perros de hogar. Y otros, especialmente en Valparaíso, en Chile y en las ciudades polvorientas de América Latina, que no tienen dónde vivir, que son perros vagabundos, andrajosos y pulguientos, excluidos del sistema, perros que deambulan hambrientos por las calles, desnutridos, mal olientes, rengueando o plagados de yagas, tumores y garrapatas.

Por otra parte, en la sociedad globalizada crecen y crecen los servicios para las mascotas, crecen las industrias de la alimentación, de la salud, de la vestimenta, del acicalamiento, de los seguros y de la vivienda para perros. Hay desde hospitales, restaurantes, peluquerías, viviendas, hoteles, cemen-

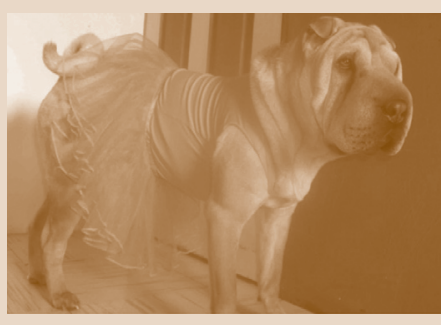


terios, hasta Isapres, sesiones de aromaterapia y sicólogos para perros. Hay también un mundo de libros, revistas y programas de TV sobre perros, especialmente en los Estados Unidos. El mercado de accesorios y del glamour para las mascotas pudientes también ha aumentado de manera considerable: se fabrican desde collares personalizados hasta chalecos, zapatos, calcetas deportivas, perfumes, lentes de sol y pelucas. Marcas como Gucci, Burberry y Louis Vuitton dedican colecciones especiales a esa nueva moda. Perros y perritas enchulados circulan por la Avenida Perú en Viña del Mar, por las tiendas de Alonso de Córdoba, en Santiago, y por doquier. Incluso hay modas por adquirir ciertas razas, demandas que convierten a los propios perros de pedigree en objetos de comercio, lo que da pie a una industria de la producción selectiva. El mundo de los perros se ha integrado, entonces, plenamente, a un modelo de vida consumista.

En los medios de comunicación y en las letras contemporáneas abundan historias y crónicas que relatan las cada vez más estrechas relaciones entre perros y seres humanos. O que dan cuenta de las capacidades y sentimientos de los perros. Ahí está el video de ese perro que en una carretera rescató -como pudo- a otro perro, corriendo peligro de su propia vida, socorriendo así a un perro ensangrentado que había sido atropellado minutos antes por un vehículo que se dio a la fuga. Ahí está el relato del novelista francés Jean Giono, quien vivió en un pequeño pueblo de los Alpes franceses, y que cuenta el caso de su perro Cadet que alguna vez lo acompañó al cine y que más tarde siguió asistiendo solo, de modo regular y por propia iniciativa, al cine del pequeño pueblo de los Alpes marítimos. Ahí está la crónica de Joaquín Edwards Bello que escribió " ¿Han notado que nuestro pueblo, no ama muchas cosas, pero se haría matar por su perro? ¿Han presenciado el pánico que produce el paso de la perrera?" (Calderón, 2009). Ahí está Sigmund Freud, que algo sabía del intrincado mundo de los seres humanos, el Freud que en una entrevista de 1926 dijo: “¿Qué objeción puede haber contra los animales?" Y luego señaló, pensando en su perro: "Yo prefiero la compañía de los animales a la compañía humana", "las emociones del perro, nos recuerdan a los héroes de la antigüedad. Tal vez esa sea la razón por la que inconscientemente damos a nuestros perros nombres de héroes como Aquiles o Héctor" (Freud, 1957). Ahí está Psychentral, la revista virtual de sicología en que la Dra. Suzanne Phillips argumenta que debemos observar y aprender de las relaciones que tenemos con nuestros perros y mascotas para mejorar las relaciones que tenemos con nuestra pareja. Ahí está el caso de ese perro japonés -Hachiko- que solía esperar todos los días a su amo en la estación de tren cuando éste llegaba de dictar su clase en la 
Universidad de Tokio, y que luego de que su amo sufriera un derrame cerebral mientras dictaba su curso, Hachiko siguió esperándolo en la estación de trenes por años y años, situación que dio origen a una película y a una estatua que honra su lealtad.

Son relatos que, sumados a los datos duros que señalamos anteriormente, contribuyen a la constatación de que paulatinamente se ha producido una osmosis entre la sociedad humana y la sociedad perruna. Se da el caso de amos que han dejado herencias suculentas a sus canes, a perros que poco o nada entienden del tema. Resulta significativo que la publicidad de los alimentos para perros que hacen las multinacionales no está orientada a los perros sino a los gustos y costumbres de los seres humanos. La comida que fabrican es alimento para perros, pero las ilusiones que venden apuntan a consumidores humanos. El discurso de la hermandad y amistad hombreperro está ya bien instalado en el imaginario social. Cada vez más los perros son concebidos como seres humanos. El antropocentrismo funciona entonces en dos planos: en el de la amistad, compañía y cariño, por un lado, como si el perro fuese un amigo o un hijo, y en el del consumismo, por otro.

Ahora bien, como es evidente, casi nada de esto ocurre por voluntad o iniciativa de los propios perros. Se trata de un constructo de representaciones y de realidad que corre paralelo a una creciente sofisticación en la domesticación, y amistad hombre-perro, y a un desarrollo y volumen cada vez mayor de la industria y del negocio de las mascotas, en una lógica de mercado. Una proyección hacia el mundo canino del imaginario social humano, un intercambio simbólico (unilateral) que paradojalmente revela la (proyectada) humanidad de los animales y, subrepticiamente, la insociabilidad o soledad de la fisonomía espiritual del hombre contemporáneo. Hablamos de intercambio simbólico considerando que símbolo es aquello que hace ver en un objeto, entidad -y en este caso en un perro- algo distinto a sí mismo. En definitiva, la "máquina antropocéntrica" funcionando vertiginosamente, en un mundo canino que con sus vicios y virtudes se ha convertido en un espejo oblicuo del mundo del capitalismo tardío y globalizado que habitamos.

Hablamos del escenario perruno como un espejo de ese mundo, porque con respecto a él también opera el pensamiento crítico (sobre todo en los Estados Unidos). Se trata de una mirada crítica que sostiene que animales y humanos habitamos el mismo barco y que lo que ocurre con unos involucra necesariamente a los otros. Una mirada que promueve la necesidad urgente de estibar la carga -de animales y naturaleza- para que el barco no termine de hundirse. Como veremos más adelante, este pensamiento tiene 
su expresión en la crítica al antropocentrismo y al humanismo que realiza la filosofía contemporánea, pero también en el pensamiento político y en el planteamiento de una nueva generación de derechos. Se habla de una "primera generación de los derechos humanos" refiriéndose a la familia tradicional, al derecho a la integridad física, al derecho de propiedad y al derecho a la vida, derechos que emanan de la ética cristiana de Occidente; luego de una "segunda generación de derechos humanos" que corresponde a aquellos que emanan de la revolución francesa y de la Ilustración: son los derechos vinculados a la razón y a la libertad, a la libre conciencia, a la libertad de prensa y política, son los derechos asociados a la noción de ciudadano y de democracia. Pero por sobre estos derechos, que conforman la base de la Declaración Universal de los Derechos Humanos (1948), presenciamos hoy día una nueva generación de derechos, afín a las ideas de alteridad y diferencia; se trata de los derechos a la autodeterminación de los pueblos originarios y de las minorías étnicas, los derechos de reproducción, los derechos de las minorías sexuales, los derechos de los animales, los derechos llamados también "derechos humanos emergentes" que apuntan a reconocer -más allá del Estado y del parlamento- el rol de las organizaciones de la sociedad civil. La sociedad norteamericana, que ha sido, por una parte, motor del antropocentrismo y del capitalismo trasnacional, ha sido también el centro dinamizador de las corrientes intelectuales que han deconstruido críticamente este proceso. Se trata de una bipolaridad de la nación norteamericana que se proyecta en las nuevas tecnologías y en las redes sociales, bipolaridad que parece ser funcional a una extraña convivencia entre libertad, democracia y un autoasignado rol de gendarme o Pitbull del mundo.

El movimiento por los derechos de los animales, que forma parte de este pensamiento contestatario, se propone defender a los animales de todo abuso y explotación, y otorgarles los mismos derechos de los humanos, estableciendo así una suerte de equiparidad entre la condición animal y la condición humana. Desde esta perspectiva, el movimiento por los derechos de los animales discute la supuesta excepcionalidad humana, señalándola como un prejuicio o como una fantasía (Haraway, 2008). En el plano de la alimentación postula un comportamiento vegano, rechazando los alimentos que provienen del mundo animal. Se pretende evitarles a los animales el sufrimiento y todo tipo de abuso, en última instancia devolver las manillas del reloj hasta antes del arca de Noe, de modo que las mascotas regresen a su ambiente natural, lo que implica tácitamente -así se piensa- asumir el punto de vista del otro. El movimiento por los derechos animales en 
esta versión radical se diferencia de un movimiento paralelo: aquel que promueve el bienestar y buen trato a los animales. El primero plantea una crítica a la domesticación y al uso con fines antropocéntricos de los animales (sea en zoológicos, mataderos, alimentación, industria de pieles o lana, laboratorios, criaderos o simplemente como instancia de compañía, etc.). De hecho, en los Estados Unidos, las dos posturas se han enfrentado en una polémica semántica y lingüística: las varias asociaciones que forman parte del movimiento por los derechos de los animales promueven el concepto de "guardián" (sea de perros o de mascotas) en lugar del concepto de "amo", prerrogativa esta última que defienden las asociaciones vinculadas a la tenencia responsable y al buen trato, postura que comparten también las asociaciones de dueños de perros y mascotas. El concepto de "guardián" implicaría un respeto por la autonomía y por el punto de vista de los perros y de los animales, mientras el concepto de "amo" tendría una connotación afín a la "máquina antropocéntrica". Para los partidarios de la tenencia responsable, el activismo por los derechos de los animales de Peter Singer y otros líderes de ese movimiento pretendería en última instancia romper el lazo posesivo entre humanos y perros, o, en general, entre humanos y mascotas (Lorscheider-House, 2003). Frente a esa pretensión, los partidarios de la tenencia responsable argumentan que en la naturaleza los animales se ven enfrentados a una lucha por la sobrevivencia, y a escenarios bastante más crueles o amenazantes que los que se dan en la convivencia entre animales y humanos.

Más allá de esta polémica, lo que interesa recalcar es que las ideas y el activismo de ambas corrientes: la de los derechos de los animales por un lado y la del bienestar de las mascotas, por otro, ha ido tomando cada vez más fuerza. Y hoy día está presente no sólo en los Estados Unidos sino también en América Latina, y en Chile. Recientemente en la Municipalidad de Lo Prado, y en otras comunas de sectores populares de Santiago, los vecinos espontáneamente se organizaron para defender a los perros vagos y evitar la acción supuestamente higiénica de instancias municipales que pretendían exterminarlos. Los movimientos por los derechos de los animales o por la tenencia responsable de mascotas forman parte del escenario contemporáneo (tal como los derechos de género, los derechos étnicos o de alteridad). Son corrientes intelectuales que critican y erosionan pero también contribuyen a reacomodar las dinámicas de la "máquina antropocéntrica". Son, además, movimientos que han recibido un apoyo decidido, tanto intelectual como económico, de algunos de los más destacados escritores contemporáneos, entre otros, de John Maxwell Coetzee, premio nobel 
de literatura ${ }^{4}$, y del autor colombiano Fernando Vallejo, quien ha donado considerables sumas de dinero -obtenidas en reconocimientos y premios literarios- a asociaciones de defensa y resguardo de los derechos perrunos.

Hay algunos acontecimientos históricos de fondo que en las últimas décadas han incidido en este cuestionamiento al antropocentrismo y en una revisión de la condición humana: ellos son, entre otros, la crisis de los grandes metarrelatos del humanismo (cristianismo, ilustración y marxismo) y el consiguiente clima antiutópico; la amenaza de un sobre poblamiento del mundo con consecuencias alimentarias y de perturbación de los ecosistemas; un exceso de actividad humana y de emanaciones de $\mathrm{CO}_{2}$ que está ocasionando cambios climáticos y un calentamiento global, todo ello con imprevisibles consecuencias para la vida en el planeta; también la crisis de la Iglesia Católica como institución depositaria de valores trascendentes. Asistimos así, en la globalización capitalista de Occidente, a un contexto de notas apocalípticas que estimula la reflexión sobre el rol y significación de la condición humana, un contexto que ha llevado a revisar una tradición filosófica en que la autopercepción de lo humano se contrapone a la percepción de lo animal.

\section{VARIABLE ESTÉTICO-LITERARIA}

Las representaciones perrunas circulan, como ya señalamos, en distintos soportes: desde la oralidad hasta las artes plásticas y el audiovisual ${ }^{5}$. Pero es sobre todo la literatura el soporte en que estas representaciones alcanzan mayor complejidad y densidad significativa. El lenguaje literario, en sus distintos géneros, tiene la capacidad de indagar en la condición humana de un modo distinto al lenguaje racional. Es un modo de conocimiento que -sin proponérselo-construye a partir del lenguaje una realidad imaginaria viva, en trance de ocurrir, una realidad en que la verosimilitud de la ficción -producto de la coherencia estética- llega a ser más contundente y profunda que la verdad histórica o que el discurso lógico y racional ${ }^{6}$. La palabra y el lenguaje literario ocupan un lugar de privilegio en el desocultamiento de los

\footnotetext{
${ }^{4}$ Autor de The life of animals (1999); y Elizabeth Costello (2003), obras en que la defensa de los animales es tema central.

${ }^{5}$ Sobre arte y animales, véase Steve Baker "Kac and Derrida: Philosophy in the wild?" Symposium "The aesthetics of care? University of Western Australia, agosto, 2002, y The postmodern animal (2000).

"Idea que ya está en la Poética de Aristóteles (2003), también en "El origen de la obra de arte" de Martín Heidegger (1965).
} 
espacios más íntimos y recónditos de la condición humana, y de sus modos de estar en el mundo. Estamos conscientes de que la literatura es un fin en sí mismo, y desde este punto de vista irreductible a un discurso racional. Sin embargo, ello no significa que la obra de arte quede fuera del dominio de lo racional. No es casual, en esta perspectiva, que la literatura se adelante al discurso de la razón o al pensamiento filosófico y científico, como ocurre, como veremos, con el corpus que hemos seleccionado.

Podemos entonces postular que la narrativa perruna resulta un campo privilegiado para indagar aspectos de la condición humana vis a vis la condición animal. Pero cuando señalamos que la verosimilitud y el desocultamiento de la verdad profunda -que es la verdad que revela el arte- está vinculado a la coherencia estética, estamos afirmando que necesariamente tendremos que abocarnos a lo literario de la literatura. Ello implica prestar atención al modo narrativo, describir su tono y su punto de vista, preguntarnos por la voluntad de composición que subyace a esos rasgos. Distinguir aquellas obras que son narradas total o parcialmente por perros, de las que recurren a un narrador personal u omnisciente; examinar también si los narradores o personajes-perros son perros humanizados o una mixtura de perro y ser humano, o simplemente perros perros. Interpretar ficciones en que hay canes que piensan y tienen ideas políticas y sociales, pero que también mueven la cola y persiguen y olfatean a perras. Tener presente, además, que hay relatos -como "Investigaciones de un perro", de Kafka- en que la coherencia estética del punto de vista narrativo está lograda en base a incoherencias, a una voz narrativa que fluye sin intermitencias entre su condición humana y su condición animal. Destacar las voces perrunas que resaltan la dignidad animal y critican la autoproclamada superioridad de la especie humana (cuestión que está presente, entre otras, en las novelas de Juan Rafael Allende, Jack London y Luis Rafael Sánchez). Examinar la construcción de personajes, el carácter y los logros de las representaciones simbólicas por encima de sus características formales; el vínculo entre la trama y el argumento, habrá que considerar también las transformaciones en el género narrativo, el tipo de lector apelado y la recepción que tuvieron en su época algunas de estas obras.

Cuando se lee una novela como Memorias de un perro, escritas por su propia pata, leemos una obra de Juan Rafael Allende publicada en 1893, pero leemos también una tradición: la de la novela picaresca. Se hace necesario, entonces, explicitar la apropiación y diferencia de esa novela con respecto a la tradición picaresca, el modo en que se continúan o se alteran una serie de convenciones literarias de larga data. En esta perspectiva, la intertextualidad, entendida como el conjunto de relaciones que se ponen de

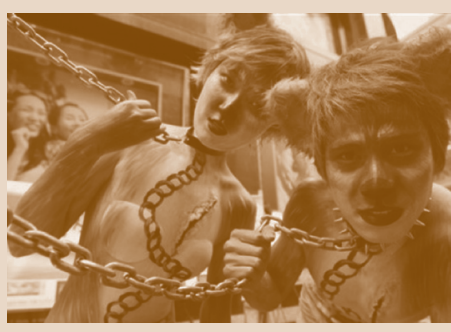

BIBLIOTECA DEL PONCIO PLATOS: MEMORIAS

\section{UN PERRO} POR SU PROPIA PATA

SANTIAGO DE OHILE IMPRENTA B. VICUÑA MACKENNA $1 \overline{893}$ 
manifiesto en el interior de un texto determinado, deviene un aspecto fundamental. Las obras que se inscriben en un registro -sea éste el de la novela picaresca, el opus cervantino o el subgénero autobiográfico y memorialistasuelen atraer un tejido de convenciones, citas y referencias, las que despliegan su virtualidad significativa en la medida que se las explicita como tal. Se trata también de constatar la presencia o ausencia en la novela de discursos de época que pueden estar -desde el punto de vista estético y literario-bien o mal integrados a la obra. En el caso de la novela de Juan Rafael Allende: el discurso anticlerical satírico y burlesco. $\mathrm{O}$ el discurso sobre el hambre en la posguerra en el relato "Señor y perro" de Thomas Mann, el discurso evolucionista en las novelas de Jack London, y el discurso tecnológico en Indiscreciones de un perro gringo, de Luis Rafael Sánchez.

En la mayoría de las obras del corpus, tras el discurso de los hechos y de las acciones narradas, se desarrolla otro discurso: el de las ideas (Segre, 1985). En el Coloquio de los perros (1613) Cipión y Berganza ironizan con una óptica renacentista sobre la poética del "deleitar enseñando", sobre las "murmuraciones" y las "prédicas", aludiendo así a la importancia de una concepción estética opuesta a la poética moralizante postridentina, una concepción en que la literatura se impone como literatura, como un fin en sí misma, y en que por ende el sentido estético circunvala al sentido ético, la razón a la religión. En La quijotita y su prima (1815) rige el ideario ilustrado, el ideal de la educación y el cultivo de la razón, y una visión de los perros como entes carentes de estos dones, perspectiva por ende vinculada más al pasado colonial y al discurso barroco que al mundo moderno. En Las aventuras de cuatro remos (1883) y Memorias de un perro (1893) rige el ideario positivista y determinista; en las novelas de Jack London el pensamiento de Darwin y el evolucionismo de Spencer, ideas que perciben al ser humano como una especie más; en Corazón de perro (1925) circula la crítica al cientificismo y a la ingeniería social alimentada por el materialismo histórico; en Investigaciones de un perro (1924) de Kafka, un existencialismo avant la lettre; en Indiscreciones de un perro gringo (2007) el discurso del transhumanismo y en la obra de Mario Bellatin y Fernando Vallejo el discurso posmoderno. En El hombre que amaba a los perros (2009) también el ideario posmoderno y antiutópico, pero en un registro distinto. Sin embargo, la atención y dilucidación de estos elementos ideológicos no se plantea en términos de una historia de las ideas, sino como una vía para atraer los idearios involucrados y mirar desde ellos el tema de la condición animal y la condición humana.

Otro aspecto de interés es la constatación de que la mayoría de los textos 
latinoamericanos - a diferencia de los europeos-involucran a perros vagos, a quiltros y no a perros de raza, lo cual se traduce en diferencias de tono y lenguaje, en la presencia del humor y de elementos propios de la cultura popular y de la novela picaresca. Aspectos que están ausentes en la literatura norteamericana y europea no hispánica. Cabe señalar, por último, que todas las distinciones formales o de contenido que hemos señalado no pretenden quedarse en el ámbito de lo descriptivo; la exploración de las mismas se propone esclarecer el modo en que en la literatura se indagan y deconstruyen las fronteras de la condición humana y de la condición animal, adelantándose así desde la especificidad del discurso literario a la reflexión filosófica y aportando a un tema que está hoy presente en el escenario intelectual.

\section{VARIABLE FILOSÓFICA}

En las últimas décadas se ha dado un debate filosófico sobre la condición humana y la condición animal. Básicamente, los aspectos que se discuten son dos: en primer lugar, la visión de los animales como seres carentes en comparación con los seres humanos, carentes de razón, de entendimiento, de voluntad y de lenguaje. Visión que viene desde Aristóteles (que convirtió a los animales o "brutos" en un fantasma filosófico), visión que fue posteriormente reforzada por la Biblia y el cristianismo, que sitúan a la especie humana como centro y destino de todo lo creado, y a los animales como una suerte de decorado. También por el humanismo renacentista, por Descartes ("pienso, luego existo"), por el pensamiento ilustrado, por Kant, por el materialismo histórico y por el espiritualismo conservador. "Los animales -dice el historiador Jaime Eyzaguirre- son apenas un instante fugaz e irracional dentro del existir, carecen de alma colectiva, de sentido y de esperanza en el suceder. El hombre ha recibido, en cambio, el privilegio de tener un destino, de prolongarse en el tiempo y más allá del tiempo; por eso a él le está reservado el honor de ser protagonista de la historia" (Eyzaguirre, 1969: 29). Se trata de una mirada binarista en la medida que caracteriza tanto a los animales como a la especie humana por oposición. Lo que es propio y específico del hombre en tanto ser pensante y autorreflexivo no es propio de los animales. El concepto de animal opera, entonces, como una negación de lo humano, y viceversa.

El segundo aspecto en debate es la idea de que existe una discontinuidad, una línea divisoria absoluta -fenoménica y ontológica- entre el ser 
humano y los animales, frontera que supone la superioridad de la especie humana sobre otras, y que avala la idea de que el hombre sería la culminación biológica y espiritual en el conjunto de las especies. Esta fisura fundamenta el antropocentrismo, la idea de que el hombre es el centro y medida de todo lo que le rodea. De allí que la cuestión animal, por todo lo que ella involucra, ha devenido uno de los asuntos centrales en el discurso crítico contemporáneo. Un debate en el que han participado, entre otros, los pensadores franceses Michel Foucault, Jacques Derrida, Gilles Deleuze y Félix Guattari, el australiano Peter Singer, el italiano Giorgio Agamben, y pensadores norteamericanos como Mathew Calarco, Kelly Oliver, Cary Wolfe, Cora Diamond, Clare Palmer, y Stanley Cavell, además del escritor y ensayista sudafricano John Maxwell Coetzee y algunos filósofos latinoamericanos dedicados a la ecoética, como la chilena Sandra Baquedano (Derrida, 2008; Deleuze y Guattari, 2002; J. M. Coetzee, 1999; Singer, 1999; Wolfe (Edit.), 2003; Calarco y Atterton (Eds.), 2004; Agamben, 2008; Baquedano, 2008; Haraway, 2008; Calarco, 2008; Oliver, 2009; Cavell et alia, 2009; Wolfe, 2010; Palmer, 2010). Autores que esgrimen sus ideas rescatando antecedentes o refutando reflexiones filosóficas previas sobre la condición humana y animal, de pensadores como Aristóteles, Rousseau, Nietzsche, Heidegger y Levinas (Nietzsche, 1997 [1882]; Heidegger, 1995; Foucault, 1968; Levinas, 2004). La condición animal es un tema que la academia norteamericana ha puesto en el tapete en las últimas décadas; a la filosofía animal se la considera una de las especialidades de la filosofía anglosajona contemporánea. Asumiendo su espacio en esta agenda, la revista francesa Philosophie publicó recientemente (2011) un número completo dedicado a la Philosophie animale pero francaise ${ }^{7}$.

La crítica a la soberbia humana se manifiesta en una crítica al humanismo, a un pensamiento que supone como una verdad absoluta y trascendente la posición central y el destino superior del hombre en el universo. Incluso, en unos pocos pensadores ilustrados había ya dudas al respecto: Diderot le escribe a D’Álembert: “¿Quién puede decir si este bípedo algo deforme, alto tan solo de cuatro pies, que en las cercanías del Polo se llama todavía hombre y que no tardaría en perder este nombre si se deformara todavía un poco, no es más que la imagen de una especie que pasa?" (Cit. por Agamben, 2008), Nietzsche sostenía que el ser humano es un ser ontológicamente inacabado, un puente tendido en el abismo y no una meta. Heidegger, en

\footnotetext{
${ }^{7}$ Philosophie (2011). Trae artículos de Emanuel Levinas, Clare Palmer, Patrik Llored y Brian Masumi.
} 
su Carta sobre el humanismo (2000 [1946]) critica al humanismo como un pensamiento condicionado por la metafísica (metafísica que se hace patente en la concepción universal del hombre como animal racional); lo critica como postura que en sus distintas manifestaciones ha equivocado el modo de abordar lo propiamente humano: el ser ${ }^{8}$. Foucault, a su vez, percibe al humanismo como un pensamiento egocéntrico, como un prejuicio a partir de un supuesto antropológico que establece un binarismo entre hombre y animal, una dicotomía en que lo humano se constituye en la represión de su animalidad. Peter Sloterdijk concibe al humanismo como un pensamiento ya superado, por la posibilidad de una autoproducción humana gracias al manejo de técnicas que permiten (o permitirán) recrear la especie a través de la manipulación del genoma y de los códigos genéticos, antropotécnicas que llevan a superar el dualismo de lo natural y lo artificial propio de la concepción humanista del mundo. Por otra parte, según Sloterdijk, el humanismo clásico -en tanto modelo educativo vinculado al ideal de una cultura letrada- carece hoy de vigencia, debido a la omnipresencia de la cultura de masas y a la informática. La lectura letrada dejó de ser el paradigma de la cultura (Vásquez, 2009).

Pero son sobre todo Jacques Derrida, Giorgio Agamben y algunos estudiosos norteamericanos como Kelly Oliver, Matthew Calarco y Cary Wol$\mathrm{fe}^{9}$, quienes más han avanzado en la deconstrucción del binarismo humano/animal y en la formulación de un pensamiento poshumanista. Derrida plantea que no es posible dibujar una frontera absoluta o líneas demarcatorias entre el hombre y el animal, debido a que estas líneas son múltiples y cambiables, son fronteras inestables entre los diferentes tipos de animales, incluyendo los animales humanos. Para Derrida, no se puede hablar de "lo animal" como un universal abstracto que apunta a todo lo viviente no humano, pues -según él- hay una multiplicidad de vida animal, y cada especie (incluso cada individuo de esa especie) constituye una particularidad en sí y en sus relaciones con lo humano. Levinas, por su parte, al reflexionar sobre la ética centrada en lo humano ("el Otro es siempre y solamente otro humano") piensa al perro como una excepción, en la medida que tiene "rostro" (Calarco, 2008). El posthumanismo lleva a repensar los modos de autopercepción y afectividad del homo sapiens, recontextualizándolos en términos del sensorium de otros seres vivientes y de su propio modo de

\footnotetext{
8 "Todas las clases de humanismo que han ido apareciendo -dice Heidegger refiriéndose al cristianismo, al marxismo y al existencialismo- dan por sobreentendida la esencia universal del ser humano" como animal racional, afirmación condicionada por la metafísica (Heidegger, 2000).

${ }^{9}$ Véase Baker (2000; 2002).
} 
vivir el mundo, modos que son parte de nuestra evolución. El poshumanismo es, en síntesis, un nuevo modo de pensar que surge luego de una toma de conciencia de las represiones culturales y de las fantasías propias del humanismo, un modo de autoconciencia histórica que abandona la presunción de la soberanía humana y de su arrogancia de ocupar un lugar destacado y único sobre todo lo viviente (Wolfe, 2010).

Giorgio Agamben es tal vez quien ha puesto con más perspicacia en la mesa crítica a la "máquina antropocéntrica". El filósofo italiano distingue en el hombre su vida vegetativa u orgánica (el funcionamiento del corazón, la circulación de la sangre, los intestinos, el hambre, etc.) y su vida de relación con el Otro y el entorno. La vida vegetativa es ciega y privada de conciencia, una vida que merece -dice Agamben- el nombre de animal. Lo animal y lo humano pasan por ende por el interior del viviente-hombre en términos de una frontera móvil. Esta vida animal del hombre ha sido reprimida y separada de la vida de relación, lo que constituye, según Agamben, la base sobre la cual se opone el hombre a los otros seres vivientes. "Si la cesura entre lo humano y lo animal pasa sobre todo por el interior del hombre, entonces la cuestión del humanismo debe ser formulada en nuevos términos". ¿Cuáles son esos nuevos términos, para Agamben? "En nuestra cultura -dice- el hombre ha sido siempre pensado como la conjunción entre un cuerpo y un alma, un viviente y un logos, un elemento natural"- o animal- " $y$ un elemento sobrenatural, social o divino. Tenemos que aprender a pensar al hombre como lo que resulta -dice- de la desconexión de estos dos elementos y no investigar el misterio metafísico de la conjunción, sino el misterio práctico y político de la separación. ¿Qué es el hombre, si siempre es el lugar... y el resultado de divisiones y cesuras incesantes?... Es urgente trabajar sobre estas divisiones, preguntarse de qué modo -en el ser humano- el hombre ha sido separado del no-hombre y el animal de lo humano..." (Agamben, 2008). Agamben cita el caso de una niña lobo encontrada en un bosque a los diez años, en cuyo modo de actuar la razón y la sensibilidad animal se prolongan una en otra a través de transiciones imperceptibles. Tanto Agamben como Calarco rescatan -en una revisión del pensamiento de Heidegger-su intento de pensar el Ser del animal desde términos no antropocéntricos, se trata de examinar el modo específico del Ser de los animales, en sus relaciones de mundo a partir de sus propios términos. Si los animales son también capaces de ser-para-el Otro, entonces la principal línea divisoria entre el humano y el animal tiende a desvanecerse (Calarco, 2008).

Kelly Oliver plantea que el binarismo hombre/animal y la máquina an- 
tropocéntrica están vinculados al binarismo hombre/mujer y a la máquina andrógina. La oposición hombre/animal no es para Oliver cualquier binarismo, es por el contrario - como ha planteado la filosofía de la alteridad- el binarismo más utilizado para justificar todo tipo de prácticas de exclusión. De allí la importancia -dice- de desarticular esos binarismos conceptuales y postular una ética que provenga no de la soberanía de lo humano, sino surgida de una relación de interdependencia con la tierra y sus criaturas. La autora introduce el concepto de pedagogía animal refiriéndose a todo lo que el hombre ha aprendido de los animales, entre otras enseñanzas, a volar (Oliver, 2009). En el discurso filosófico poshumanista para referirse a los animales se usa con frecuencia el término "animales no humanos", lo que implica validar la categoría paralela de "animales humanos" (Cavell et alia, 2009), uso en que lo animal es lo sustantivo y lo humano lo adjetivo.

El poshumanismo al que apuntan los autores anteriores no debe confundirse con el concepto de transhumanismo. Este último se refiere a la posibilidad de que la propia especie humana sea capaz de superar sus limitaciones intelectuales y físicas mediante el control tecnológico de su evolución como especie. Se trata de un concepto vinculado a la cibernética y a la ingeniería genética (Vásquez, 2009). Cabe por último señalar que en la América indígena, en algunas concepciones amerindias se da una cosmovisión que sin proponérselo diluye la cesura animal-hombre. Un poshumanismo avant la lettre. En efecto, en algunas tribus amazónicas se da una concepción en que el sujeto y la cultura serían la forma de lo universal y los cuerpos la forma de lo particular. Una cosmovisión en que la forma material de cada especie -incluida la humana- es solo un envoltorio, una "ropa" que esconde una forma interna humana, "normalmente visible a los ojos de la propia especie o de ciertos seres transespecíficos como los chamanes" (Viveiros de Castro, 2004). Esa forma interna es el espíritu del animal: "una intencionalidad o subjetividad formalmente idéntica a la conciencia humana, materializable en un esquema corporal humano, oculto bajo la máscara animal". Tendríamos entonces a primera vista -señala el antropólogo Eduardo Viveiros, autor de un interesante trabajo sobre el tema- "una distinción entre una esencia antropomorfa de tipo espiritual, común a los seres animados, y una apariencia corporal variable, propia de cada especie: esta apariencia no sería un atributo fijo, sino una ropa intercambiable y desechable". En resumen los animales son percibidos por los amerindios como gente, como personas, como espíritus. El referencial común a todas las criaturas de la naturaleza no sería el hombre en cuanto especie, sino la humanidad en cuanto condición espiritual. Todos tenemos el mismo espí- 
ritu humano, pero el rótulo es diferente. En definitiva, en la cosmovisión amerindia humanidad y animalidad vendrían a ser una y la misma cosa, lo que coincide con el planteamiento utópico de Giorgio Agamben.

\section{VARIABLE CIENTÍFICA}

¿Es acaso el animal humano una especie privilegiada, única y con garantías de eternidad?

Las investigaciones y publicaciones de Charles Darwin (El origen de las especies, 1858 y El origen del hombre, 1871) constituyen una base de conocimiento que implica un antes y un después en el estudio de la especie humana y su relación con otras especies. Darwin sigue el camino de la ciencia de su época: observar, recopilar datos, analizarlos y construir una teoría adecuada. En la teoría de la evolución prescinde de explicaciones sobrenaturales o teológicas. "El hombre - dice Darwin- desciende de una cuadrúpedo hirsuto y dotado de cola, probablemente arborícola". Afirmación que ya contiene la idea de la superposición de la condición animal y la condición humana. Para Darwin el hombre comparte con los mamíferos en general y con otros primates en particular una constelación de rasgos bioquímicos, fisiológicos y de desarrollo. El hombre como los animales y las plantas también ha estado sujeto a la selección natural. El neodarwinismo contemporáneo, por su parte, ha contribuido a un vaciamiento de las pretensiones totalizantes del especieísmo ${ }^{10}$. Considerando los primeros organismos unicelulares se estima que en el curso de más de cuatro mil millones de años han habitado el planeta unas tres mil millones de especies de las cuales un $99 \%$ están extintas. Su aparición o desaparición "no obedece a ningún plan preconcebido... a ningún gran diseño" es nada más que el trabajo del tiempo sobre la materia y la selección natural (Brunner, 1999). En la evolución no hay un significado o propósito teleológico, "no es progresiva en la acepción valórica del término", está sujeta al azar, y lejos de ser -como pensaba Darwin- un río tranquilo, experimenta los avatares de accidentes y cambios abruptos. Según el paleontólogo y biólogo norteamericano Stephen Jay Gould, la "revolución de Darwin... se

\footnotetext{
${ }^{10}$ El especieísmo es la creencia que afirma la superioridad de una especie (la humana) en detrimento de las demás, preconiza la separación o segregación de otras especies (Baquedano, 2008).
} 
completará cuando... nos hagamos cargo de la no predictibilidad y la no direccionalidad de la vida y cuando tomemos en serio" eso de que el hombre es "sólo una minúscula brizna, recién nacida ayer, en el enorme árbol de la vida" (Brunner, 1999). La antropóloga inglesa Jane Goodall, que ha estudiado por décadas el comportamiento de gorilas y chimpancés, señala que "nuestra herencia primate determina muchas de nuestras conductas, en tal herencia -dice- están profundamente arraigadas nuestras conductas agresivas así como nuestros impulsos altruistas". Debemos aceptar-según la etóloga británica- que los humanos no somos los únicos animales con personalidad, ni los únicos capaces de resolver problemas, ni los únicos en experimentar alegría, tristeza y desesperación, ni los únicos en conocer el sufrimiento, lo que debiera reducir nuestra arrogancia y eliminar nuestra creencia de que los humanos tenemos un derecho inalienable sobre otras formas de vida para nuestro propio beneficio (Goodall, 2003).

Desde el punto de vista de las bases biológicas del comportamiento animal y humano, la supervivencia de unos y otros depende de la habilidad para obtener alimento y refugio, encontrar pareja, producir descendencia, protegerse de los elementos externos y evitar depredadores (Zerda (Ed.), 2010). El hambre, la sed, la apetencia sexual y la somnolencia son impulsos compartidos por el animal humano y por el no humano, impulsos que tal como las emociones obedecen a estados internos del organismo y del sistema nervioso. Algunos de estos estados son la incorporación o ingestión de alimentos, la expulsión y liberación de lo dañino para el organismo; la destrucción de lo que se opone a una necesidad y la reproducción que permite que el organismo se perpetúe en organismos similares. Según Jay Gould nuestros antepasados fueron bípedos (desde hace aproximadamente un millón y medio de años) mucho antes de tener una capacidad cerebral que los distinguiera realmente del resto de los primates (Gould, 1997). El bipedismo fue modificando el cerebro, el sistema nervioso y la sexualidad humana (Zerda (Ed.), 2010). Desde el punto de vista biológico y neurofisiológico, hay una enorme proximidad entre la especie del animal humano y los animales, sobre todo con los animales que tienen un cerebro más grande y son bípedos como los chimpancés y los gorilas.

Desde la ciencia, la autopercepción de la especie humana con respecto a otras especies nos conduce a una mirada de asombro, humildad y hermandad. Cabe señalar, sin embargo, que no todos los científicos comparten esta perspectiva. El estudioso austriaco Konrad Lorenz, uno de los fundadores de la etología, señala que el mayor conocimiento del comportamiento animal en su fase más avanzada de evolución, no conduce -dice-, como mu- 
chos creen, a una reducción de las diferencias entre hombre y animal, sino todo lo contrario. Para Lorenz, sus investigaciones lo han llevado a concluir que efectivamente en el hombre "se encuentra todo lo animal, pero no es cierto que en lo animal se encuentra todo el hombre" ${ }^{11}$. Lorenz explica su punto de vista señalando que los animales obedecen ciegamente a sus instintos, en ellos todo impulso interior es "bueno", no hay conflicto entre sus apetencias naturales y un "deber". En el hombre, en cambio, se habría perdido esta "sincronía" que él califica de "paradisiaca". Según Lorenz, logros específicamente humanos como el lenguaje oral y el pensamiento racional, le habrían permitido a la especie humana acumular un saber común y una ética que lo lleva a no entregarse ciegamente a sus instintos y a su trasfondo atávico (Lorenz, 1975). Filósofos del lenguaje, lingüistas y pensadores de distintas disciplinas humanas coinciden con esta perspectiva, valoran sobre todo la invención del lenguaje y las palabras, como una posibilidad de relaciones inéditas y complejas entre el ser humano, la sociedad y su entorno.

¿Son acaso el lenguaje y la razón capacidades exclusivas de la especie humana?

La respuesta es sí, si se los considera desde el punto de vista antropocéntrico y con una mirada autista desde el especieísmo humano ${ }^{12}$; pero no si se los contempla desde el punto de vista de la biología del conocimiento y de la comunicación de todas las especies. El lenguaje y la razón no son innatos a la especie humana, emergen en un momento de la evolución del hombre. Según Humberto Maturana y Francisco Varela la aparición del lenguaje en los homínidos tempranos tiene que ver con las relaciones interpersonales y afectivas asociadas a un contexto de recolectar y compartir alimentos. Hablan de estructuras ontogénicas en la medida que el lenguaje corresponde a una conducta aprendida en un proceso de interacciones vinculado a las características únicas de la vida social en una etapa de recolectores y cazadores (Maturana y Varela, 1986). En términos de desarrollo comparativo, la criatura humana es un cachorro que nace prematuro; al llegar al mundo está tan desprovisto y es tan inadaptado para sobrevivir, que está obligado a establecer lazos de apego o afectivos con los demás. Es esa prematuración, el tamaño del cerebro (con la consiguiente complejificación del sistema

${ }^{11}$ Konrad Lorenz (1975) reconoce empero la presencia de ciertas conductas enraizadas en todas las especies, incluyendo al hombre, como la agresividad.

${ }^{12} \mathrm{El}$ especieismo equivale al racismo, pues considera una especie (la humana) superior a otras (Baquedano, 2008). 
nervioso) y el entorno social los que brindan la posibilidad del lenguaje. La aparición del lenguaje en el hombre está vinculada -sostienen Maturana y Varela- al fenómeno de lo mental y de la conciencia de sí como la experiencia más íntima de lo humano (Maturana y Varela, 1986).

¿Pero qué ocurre con las otras especies? ¿Tienen acaso lenguaje y vida mental? ¿Qué nos dicen los biólogos y los zoólogos al respecto? Ya el propio Darwin señalaba que la diferencia en inteligencia del ser humano y de otros mamíferos es una cuestión de grado y no de especie. Cuando se comparan capacidades de las distintas especies hay que tomar en cuenta los experimentos del fisiólogo sueco Jacob von Uexküll, que lo llevaron a concluir que cada especie percibe su mundo con coordenadas espaciales y temporales diferentes, de modo que el bosque del lobo no es el mismo bosque que el de la lechuza o el del leñador, así también el lapso de un minuto para la mosca no es el mismo lapso de tiempo para la abeja, ni para la garrapata ni para el perro (Von Uexküll, 1974). El estudio de la vida de las abejas ha descubierto que entre ellas se da un sofisticado sistema de comunicación en que intervienen mecanismos químicos (olores, feromonas), auditivos (sonidos) y mecánicos (danzas y movimiento) (Nates, 2010) ${ }^{13}$. Las abejas incluso son capaces de manejar conceptos abstractos, lo que pone en entredicho -según un estudio del CNRS de Francia- el supuesto de que el saber conceptual requiere de un cerebro de tamaño mayor ${ }^{14}$. Según Maturana y Varela, gorilas y chimpancés han aprendido a comunicarse mediante el Ameslan (American Sign Language), el idioma internacional que usan los sordomudos. Los estudios de los insectos sociales (abejas, hormigas) y de los animales han mostrado que no puede condenárseles al silencio por el solo hecho de que carecen de lenguaje o de comunicación verbal, pues múltiples experimentos muestran que el lenguaje y la comunicación pueden ser gestual, postural, olfativo, ritualizado o químico. Chimpancés, golondrinas y perros emiten sonidos que transportan mensajes, incluso se ha estudiado la comunicación interespecies a través de posturas, gestos y secreciones corporales. Estudios contemporáneos han demostrado que en los perros los diferentes ladridos y gruñidos constituyen una especie de lenguaje, en que hay elementos de entonación, de pausa, de volumen y de contexto situacional. Los scanners muestran -según el etólogo colombiano William González- que los animales -particularmente los monos, los perros y los

\footnotetext{
${ }^{13}$ Las feromonas son sustancias químicas secretadas por los seres vivos con el fin de provocar comportamientos específicos en otros individuos.

${ }^{14}$ Investigación reseñada en El Mercurio, Santiago, 22-04-2012.
} 
gatos- recuerdan lo que hacen (tienen memoria), pueden aprender (tienen algún grado de inteligencia) y que no sólo reaccionan por estímulos o por comportamientos preprogramados (González, 2010). La capacidad de aprender y de adiestramiento de los animales es un indicador de inteligencia. Numerosos estudios científicos avalan que los animales poseen, en grado variable, razonamiento, sentimientos y comportamiento inteligente con capacidad para aprender, y también -sobre todo los perros y los gatosinteligencia emocional.

Konrad Lorenz señala que sus investigaciones le han permitido constatar una diferencia individual entre seres vivos: cita el ejemplo de dos hamsters o de dos gansos que llegan a tener personalidades marcadamente distintas, "esto ocurre -señala- en mucho mayor medida en el caso del perro que, como animal domesticado, muestra incluso en el comportamiento una gama extraordinariamente amplia de variaciones individuales" (Lorenz, 1975). Los animales sufren y son capaces de sentir placer y tener sentimientos. En los Estados Unidos se han publicado numerosos libros científicos y también de difusión sobre las emociones y conductas de los perros. Un clásico es Genetics and the social behavior of dogs (1965) de John Paul Scott y John L. Fuller. Obras que parten del supuesto de que los perros y los gatos tienen emociones, temperamento, carácter, recuerdos y un mundo síquico y mental complejo. Según el veterinario belga Joe Debasse, experto en sicología animal, "el 10\% de la población canina sufre desórdenes mentales" ${ }^{\prime 5}$. De hecho en algunos países -e incluso en Chile- hay etólogos clínicos y veterinarios que tratan en las mascotas patologías de ansiedad, miedo, soledad y depresión, y lo hacen con medicamentos o programas de modificación de conducta. En definitiva, el estudio del comportamiento de los animales desde la ciencia desvirtúa -tal como viene ocurriendo desde hace tiempo en la literatura- la visión tajante del animal como un ser -en comparación con el hombre- carente de "logos" y de lenguaje.

¿Qué efectos ha tenido la domesticación en el comportamiento animal?

El gato y el perro son las únicas especies que el hombre no sometió por la fuerza a la domesticación, sino que ese proceso se fue dando en una relación de mutuo interés. Ya Darwin reparó en que con la domesticación se producían cambios en los instintos y en algunos rasgos de los perros. Seña-

15 “Conozca la personalidad de su mascota”, El Mercurio (Santiago), 22 de octubre 2011. 
laba, por ejemplo, que las orejas caídas eran una consecuencia del desuso de los músculos de la oreja por no tener que estar los perros domesticados constantemente alertas ante el peligro, como tenían que estarlo sus antecesores los lobos o los perros salvajes. Los instintos son pautas heredadas de comportamiento, conductas innatas no aprendidas, desarrolladas en función de mecanismos de adaptación. La historia del perro indica que con el tránsito de lobos a perros, y luego con la domesticación, los perros fueron reduciendo o modificando ciertos instintos como la depredación, la agresión, la defensa y la dominación o liderazgo. Resulta destacable que ciertos perros cuiden ovejas o ayuden al pastoreo de rebaños, lo que es contrario a su ancestro de lobo depredador. Por otro lado resulta también sorprendente que los perros domesticados entierren y escondan huesos, no olvidando así su pasado de lobos. El perro domesticado conserva en sus genes rasgos atávicos pero también varía y se adapta. Los animales domesticados -afirmaba Darwin- varían más que los que se encuentran en estado de naturaleza, como consecuencia de las condiciones y entornos cambiantes a que están sometidos En el animal en estado natural los impulsos instintivos están regulados de forma que siempre contribuyen al bienestar propio y de la especie a que pertenece (Lorenz, 1975). Los perros domesticados, en cambio -y el hombre, que también es una especie domesticada-, apagan ciertos instintos o los tienen en algún lugar de su mente o en un baúl de recuerdos ancestrales. Todos hemos presenciado alguna vez cómo ante el revoloteo inocuo de una polilla o de una mosca, los gatos adoptan la postura sigilosa y expectante del leopardo a punto de cazar. Los perros y en general los animales domesticados han demostrado una gran capacidad de aprendizaje y de evolucionar acorde a los hábitos de su entorno. Ello explica que existan actualmente más de 400 razas de perros.

Hay un interesante ensayo de José Ortega y Gasset sobre la montería y el cazador solitario, en que plantea que en el ejercicio de esa ocupación el hombre revive sus instintos de cazador primigenio y retorna a sus maneras atávicas. Desde el punto de vista zoológico el hombre -igual que el perro domesticado- es un animal degenerado. Pero en "la caza", dice Ortega, se da una renuncia, en vez de hacer todo lo que como hombre podría hacer, restringe voluntariamente sus dotes " $y$ se pone a imitar a la Naturaleza; es decir, que por su gusto retrocede y reingresa en ella" (Ortega y Gasset, 1986 [1943]). El cazador actúa como hombre primigenio, revive sus instintos agresivos y depredadores tal como el gato que se pone en función de leopardo ante una insípida polilla.

La capacidad del animal humano y no humano de mimetizarse y regu- 
lar sus instintos, hábitos y conductas de acuerdo al entorno y a experiencias nuevas, encuentra una evidencia sorprendente en el caso de los niños ferales o niños lobos. Se han estudiado varios casos de niños abandonados, criados por animales y aislados de un medio ambiente humano ${ }^{16}$. Encontradas por el reverendo J. A. L. Sing en 1920, las niñas Amala (6 años) y Kamala (3 años) de la India, estaban en las afueras de Midnapore, en la madriguera de unos lobos, amparadas por la loba madre como si fueran sus propios cachorros. Los ojos les brillaban en la noche, eran agresivas, arañaban, mordían y atacaban a quienes se les acercaban. Su recuperación y readecuación en un orfanato fue imposible, enfermaron y a los pocos años fallecieron. En Ucrania, en 1983, se rescató a Oxana Malaya, niña que abandonada al nacer por sus padres alcohólicos fue criada por perros salvajes, adoptando sus conductas y modales. Oxana se comunicaba con ladridos y gruñidos, dormía acurrucada, comía sobras y carne cruda y tenía muy agudizados los sentidos de la vista y el olfato. Hasta hoy día se la puede visualizar en Internet, corriendo, moviendo la cabeza y tomando agua de la llave como un perro. Su reinserción ha sido lenta y se estima difícil que llegue a ser una persona autosuficiente. Los dos casos muestran que en pocos años se dio un extraordinario proceso de adaptación, una adquisición de instintos, hábitos y conductas propios de la especie animal y del entorno que las cobijó. Son casos de una domesticación en reversa, que de alguna curiosa manera avalan la visión del mundo de las tribus amerindias del Amazonas, en el sentido de que el cuerpo es solo una "ropa", un envoltorio.

¿Es posible salirse de la máquina antropocéntrica? ¿Podemos-como seres cognoscentes- situarnos fuera de nuestra propia mirada y percepción humanas?

Si entendemos por antropocentrismo una concepción que sitúa al hombre en el centro del universo, es claramente posible salirse conceptualmente de esa "máquina", tal como lo plantea el discurso filosófico y científico contemporáneo. Pero hay preguntas del tipo de las que se hace Derrida a propósito de un encuentro con un gato: "Cuándo yo juego con un gato ¿está acaso el gato jugando conmigo?" ¿Puede uno salirse de ese "yo" y asumir ese otro, sin mí? Podemos sí pensar que ese otro es significativo y valorarlo como tal. Pero de allí a interiorizarnos del punto de vista de ese "otro", hay

${ }^{16}$ El sociólogo francés Lucien Malson habla de 131 casos en Los niños selváticos (1995). 
una distancia. En buenas cuentas, cabe preguntarse ¿si es posible además de describir -como lo ha hecho Von Uexküll- asumir plenamente las coordenadas temporales y espaciales de las otras especies, obviando la nuestra? En sus diversos estudios sobre la biología del conocer Maturana y Varela han examinado esta cuestión. ¿Cómo es posible -se preguntan- que yo mismo pueda dar cuenta de las variaciones perceptuales de mi propio mundo, incluyendo explicaciones sobre ellas, siendo que no tengo manera de situarme "fuera" de mis propias percepciones? En los estudios que se emprenden nuestra propia actividad descriptiva es parte constitutiva de los mismos, de alguna manera -según Maturana y Varela- el conocimiento y las explicaciones científicas son proposiciones generativas puesto que generan el fenómeno que explican. ¿Tenemos acaso una variable independiente a lo humano para conocer nuestro propio proceso cognitivo? La respuesta que ellos dan es que todo conocer depende de la estructura del que conoce. En base a experimentos señalan que el fenómeno del "conocer" no se lo puede considerar como si hubiesen "hechos" allá afuera que uno capta y luego los interioriza conceptualmente. Plantean la idea de una circularidad entre acción, conocimiento y experiencia: "Toda reflexión incluyendo una sobre los fundamentos del conocer humano, se da necesariamente en el lenguaje que es nuestra peculiar forma de ser humanos y estar en el hacer humano" (Maturana y Varela, 1986). Todo indica entonces que resulta imposible mirar y asumir plenamente la condición animal y la condición humana desde afuera de lo humano y sin lo humano. Puede pensárselas, pero a condición de que sea una reflexión entre paréntesis; una cosa es el pensamiento, otra la acción y otra la imagen de la acción y, tal como señala Nietzsche, "la rueda de la causalidad no gira entre ellas" (Nietzsche, 1972).

$\mathrm{Y}$ es en este punto que regresamos a la literatura y al corpus inicial, relevándolo como una forma de conocer que no tiene propósitos cognitivos, como una mirada que sobrepasa lo conceptual y la rueda de la causalidad, que a diferencia de la ciencia carece de propósitos generativos, que es más bien una aventura lingüística e imaginaria que abre lo que otros discursos cierran: de eso se trata, de aguzar el oído y escuchar qué nos dicen las representaciones literarias y culturales perrunas sobre los temas que hemos abordado ${ }^{17}$.

${ }^{17}$ El presente artículo corresponde a un capítulo introductorio de un libro en preparación. 


\section{REFERENCIAS}

Agamben, G. (2008). Lo abierto. Buenos Aires: Adriana Hidalgo.

Andrade Kabayashi, M. (2011). "Representaciones e imaginarios perrunos: desde Grecia hasta la conquista de América". Revista Universum, vol. 26, 2.

Aravena, F. (2010). “Perro mundo", Revista Sábado, El Mercurio, Santiago, 6-2.

Aristóteles (2003). Poética. Mérida: Universidad de los Andes.

Baker, S. (2000). The postmodern animal. London: Reaktion Books.

Baker, S. (2002). "Kac and Derrida: Philosophy in the wild?" Symposium “The aesthetics of care?" University of Western Australia, Agosto.

Baquedano, S. (2008). Sensibilidad y responsabilidad socioambiental. Un ensayo de pesimismo autocrítico. La Habana: Publicaciones Acuario; Centro Félix Varela.

Brunner, J. J. (1999). Globalización cultural y postmodernidad. Santiago: Fondo de Cultura Económica.

Calarco, M. (2008). Zoographies, The question of the animal from Heidegger to Derrida. N. York: Columbia University Press.

Calarco, M. y Atterton, P. (Eds.) (2004). Animal Philosophy: Essential readings in Continental Thought. N. York: Continuum.

Calderón, A. (2009). El vicio de escribir. Santiago: Catalonia.

"Conozca la personalidad de su mascota", El Mercurio (Santiago), 22 de octubre 2011.

Cavell, S. et alia (2009). Philosophy \& Animal Life. N. York: Columbia University Press.

Coetzee, J. M.(1999). The life of animals. New Jersey: Princeton University Press. (2003). Elizabeth Costello. N. York: Viking.

Darwin, C. (1909) [1871]. El origen del hombre. La selección natural y la sexual. Trad. de A. López White. Valencia: F. Sempere y Ca Editores. (2009) [1858]. El origen de las especies. Madrid: Akal.

De Castro, M. (1900). Vida del soldado español Miguel de Castro (1593-1611). Edición de A. Paz y Mélia. España: Bibliotheca Hispánica.

Deleuze, G. y Guattari, F. (2002). Mil mesetas. Capitalismo y esquizofrenia. Valencia: Ed. Pretextos.

Derrida, J. (2008). The animal that therefore I am. N. York: Fordham University Press.

Eyzaguirre, J. (1969). Hispanoamérica del dolor y otros estudios. Santiago: Editorial Universitaria.

Foucault, M. (1968). Las palabras y las cosas. Una arqueología de las ciencias humanas. Bs. Aires: Siglo XXI.

Fox, M. (1978). The dog: its domestication and behavior. New York: Garland STM Press.

Freud, S. (1957). "Entrevista realizada en 1926 por George Sylvester Viereck". Psychoanalysis and the Fut (New York). 
González, W. (2010). “Bases del comportamiento parental: etología de nuestra historia”. En: Zerda, E. (Ed.). Bases biológicas del comportamiento animal y humano. Bogotá: Universidad Nacional de Colombia.

Goodall, J. (2003). Gracias a la vida. Barcelona: Mondadori.

Gould, S. J. (1997). La falsa medida del hombre. Barcelona: Grijalbo.

Haraway, D. J. (2008). When species meet. Minneapolis: University of Minnesota Press.

Heidegger, M. (1965) "El origen de la obra de arte”. En: Heidegger, M., "Curso de metafísica de 1929-1930". The Fundamental Concepts of Methaphisics. Bloomington, USA: Indiana University Press. (1995). “Curso de metafísica de 1929-1930”. En The Fundamental Concepts of Methaphisics. Bloomington: Indiana University Press. (2000). Carta sobre el humanismo. Traducción de Helena Cortés y Arturo Leyte. Madrid: Alianza Editorial.

Jay Gould, S. (1997). La falsa medida del hombre. Barcelona: Grijalbo.

Levinas, E. (2004). "The paradox of morality”. En: Calarco, M. y Atterton, P. (Eds.). Animal Philosophy: Essential readings in Continental Thought. N. York: Continuum.

Lorenz, K. (1975). Cuando el hombre encontró al perro. Barcelona: Tusquets.

Lorscheider-House, J. (2003). Rhetoric and man's best friend. Tesis para optar al Master of Arts, Dept. of English, U. North Carolina, USA.

Malson, L. (1995). Los niños selváticos. Madrid: Alianza Editorial.

Martínez de Espinar, A. (1644). Arte de ballestería y montería. Madrid: Imprenta Real.

Maturana, H. (2010). El sentido de lo humano. Santiago: Comunicaciones Nor Este.

Maturana, H. y Varela, F. (1986). El árbol del conocimiento. Santiago: Editorial Universitaria.

Monner Sans, R. (1923). Perrología. Buenos Aires: Imprenta y Casa Editora Coni.

Nates, M. G. (2010). “¿Cómo se comunican las abejas?”. En: Zerda, E. (Ed.), Bases biológicas del comportamiento animal y humano. Bogotá: Universidad Nacional de Colombia.

Nietzsche, F. (1972). Así habló Zarathustra. Madrid: Alianza Editorial. (1997) [1882]. La gaya ciencia. Madrid: Alba.

Oliver, K. (2009). Animal lessons. How they teach us to be human. N. York: Columbia University Press.

Ortega y Gasset, J. (1986) [1943]. Prólogo a Veinte años de caza mayor, por el Conde de Yebes. En: Sobre caza, los toros y el toreo. Madrid: Alianza Editorial.

Palmer, C. (2010). Animal ethics in context. N. York: Columbia U. Press.

Philosophie 112 (2011): Philosophie animale française, Editions de Minuit, Paris, Hiver. Artículos de Emanuel Levinas ("Le paradoxe de la moralité (entretien)"; Clare Palmer ("Apprivoiser la profusion sauvage des choses existantes? Une étude sur Foucault, le pouvoir et les relations homme-ani- 
mal"), Patrik Llored ("Les deux corps sacrifiés de l'animal. Réflexions sur le concept de zoopolitique dans la philosophie de Derrida") y Brian Masumi (“Ceci n'est pas une morsure. Animalité et abstraction chez Deleuze et Guattari").

Scott, John Paul y Fuller, John L. (1965). Genetics and the social behavior of dogs. USA: University of Chicago Press.

Segre, C. (1985). Principios de análisis del texto literario. Barcelona: Editorial Crítica.

Singer, P. (1999). Liberación animal. Madrid: Trotta.

Vásquez Rocca, A. (2009). "Sloterdijk, Agamben y Nietzsche: biopolítica, posthumanismo y biopoder". Nómadas, Revista Crítica de Ciencias Sociales y Jurídicas 23,3 .

Viveiros de Castro, E. (2004). "Perspectivismo y multinaturalismo en la América Indígena”. En: Suralles, A. y García Hierro, P. (Eds.), Tierra adentro. Territorio indígena y percepción del entorno. Copenhague: IWGIA Documento.

Von Uexküll, J. (1974). Mondes animaux, monde humain. Paris: Gonthier.

Wolfe, C. (Ed.) (2003). Zoontologies: the question of the animal. Minneapolis: University of Minnesota Press.

Wolfe, C. (2010). What is posthumanism? Minneapolis: U. of Minnesota Press. Yelin, J. (2010). "La voz de su amo. De la biografía (y la autobiografía) animal”. Quimera, diciembre, 91-93.

(2011). "Kafka y el ocaso de la metáfora animal". Anclajes 15, 1.

Zerda, E. (Ed.) (2010). Bases biológicas del comportamiento animal y humano. Bogotá: Universidad Nacional de Colombia. 